\title{
DEAD TREES IN BEECH STANDS OF THE BIESZCZADY NATIONAL PARK: QUANTITATIVE AND QUALITATIVE STRUCTURE OF ASSOCIATED MACROFUNGI
}

\author{
KACPRZYK, M. ${ }^{1}{ }^{*}$ - BEDNARZ, B. ${ }^{1}$ - KUŹNIK, E. ${ }^{1}$ \\ ${ }^{1}$ University of Agriculture in Krakow, Department of Forest Protection, Entomology and Forest \\ Climatology, 31-425 Kraków, Al. 29 Listopada 46, Poland \\ (phone:+48-126625333; fax:+48-126625062) \\ *Corresponding author \\ e-mail:m.kacprzyk@ur.krakow.pl \\ (Received $14^{\text {th }}$ Dec 2012 ; accepted $22^{\text {nd }}$ July 2014)
}

\begin{abstract}
The quantitative and qualitative structure of dead standing trees and coarse woody debris as well as the occurrence of associated macrofungi were analysed in beech stands of the Bieszczady National Park. On average, $55.55 \mathrm{~m}^{3} / \mathrm{ha}$ of dead wood, of which $64 \%$ was coarse woody debris, was found in three study plots. Elevation above sea level and distance from the upper treeline had a significant impact on the quantitative and qualitative structure of dead trees in the stand. When approaching the upper treeline, the thickness of the coarse woody debris decreased, and the share of the dead standing trees increased. Similarly, the type of dead tree distribution in the study area changed from random in the lowermost stand, to regular in the middle range of elevation above sea level, and to clustered in the uppermost plot. The majority of coarse woody debris was in the II and IV degrees of decomposition, whereas dead standing trees were usually in the $4^{\text {th }}$ stage of decomposition. A total of 30 species of macromycete fungi were recorded, including 4 from the list of endangered species. Tinder fungus (Fomes fomentarius (L.) Fr.) was the most frequently observed species. It was shown that the species diversity of fungi is closely associated with the quality of dead trees. Most fungal taxa were recorded on coarse woody debris in the IV degree of decomposition and on dead standing trees in the $3^{\text {rd }}$ stage of decomposition.
\end{abstract}

Keywords: dead standing trees, coarse woody debris, beech forests, forest stand structure, spatial trees' distribution, Macromycetes

\section{Introduction}

Leaving dead trees in the forest is crucial for biodiversity conservation in forest biocenoses. Numerous authors (Piotrowski and Wołk 1975, Stevens 1997, Solon and Wolski 2002, Gutowski et al. 2004, Christensen et al. 2005, Pasierbek et al. 2007) clearly demonstrate the beneficial effects of the presence of dead wood in forest ecosystems on plant species diversity. Dead trees are the habitat for many rare and protected fungal species (Piltaver et al. 2002, Heilmann-Clausen and Christensen 2003, Nordén et al. 2004, Ódor et al. 2006, Holeksa and Maciejewski 2009, Pouska et al. 2010). Additionally, vertebrates usually use dead trees for shelter, as places for reproduction and the acquisition of food, and as a construction material (Solon and Wolski 2002, Gutowski et al. 2004, Gutowski 2006). Despite the key role of dead trees in biodiversity preservation in forests and the awareness that it is necessary to leave them in the stand, this issue is still disputed. In protected areas of mostly nonproduction function such as national parks, natural succession and the accumulation of large amounts of dead matter are generally acceptable phenomena (Przybylska et al. 1996, Pasierbek et al. 2007). In contrast, the presence of dead trees in managed stands is 
reasonable only in the absence of threats from cambio- and xylophagous insects, forest fire hazard or obstacles in conducting breeding work.

The issue of the role of dead trees in protected Polish forest ecosystems has been rather well elucidated in Białowieża National Park (BNP) (Kirby et al. 1991; Solon and Wolski 2002, Gutowski et al. 2004). In other countries, this issue has been studied mainly by Kirby et al. (1998) in Great Britain, Krankina et al. (2002) in Russia, Nilsson et al. (2003) and Ekbom et al. (2006) in Scandinavia, Jankovský et al. (2004b) in the Czech Republic, Winter et al. (2005) in Germany, and Kraigher et al. (2002) in Slovenia. The majority of references cited mainly refer to the quantity, not the quality, of dead biomass remaining in forests. However, the form and degree of decomposition of the woody material are key elements in terms of biodiversity. In view of the above, effort was made to analyse the quantitative and qualitative shares of the spatial distribution of and the macrofungal diversity associated with coarse woody debris and dead standing trees in selected beech stands of Bieszczady National Park (BdNP), which has the largest share of forest and strictly protected area of all the national parks in Poland (Winnicki and Zemanek 2003).

\section{Study area}

The research was conducted in beech stands of the BdNP, in three rectangular 0.10hectare (transect $20 \mathrm{~m} \times 50 \mathrm{~m}$ ) plots on the mountainside of Rozsypaniec $\left(49^{\circ} 3^{\prime} \mathrm{N}\right.$; $22^{\circ} 45^{\prime}$ E) (fig. 1). The locations of the transects were chosen to constitute a gradient in elevation. The centre of the first plot was located at $1035 \mathrm{~m}$ above sea level, the second at $1091 \mathrm{~m}$, and the third at $1146 \mathrm{~m}$. The study plots have a westerly aspect and were characterised by ground slope from 18 to $30^{\circ}$. The plots represent fresh montane forest habitat, with fertile mountain beech forest prevailing (Dentario glandulosae-Fagetum community). The inventoried beech stands were in the optimal stage and were multistoreyed. The conservation status of the study areas has preserved the original character of the examined stands.

\section{Material and methods}

Dead trees were inventoried in each of the study plots in August 2011. Their size, form, quantity, degree of decomposition and spatial distribution in the stand were recorded. Additionally, their associated fungi were determined to species level. When possible, fungi were identified in the field based on their fruiting bodies. Macromycetes that were not successfully identified in the field were subject to identification in the laboratory with the use of a STUDAR M microscope and fungal identification manuals (Breitenbach and Kränzlin 1986, Beran 2004). The systematics of macrofungi are given after Cooper and Kirk (2012).

Dead trees were classified into the following groups: (1) dead lying trees (both lying trees, logs and fragments thereof at least $1 \mathrm{~m}$ long and with a diameter greater than or equal to $10.00 \mathrm{~cm}$ on the thinner end), (2) dead standing trees, i.e., standing declining trees and snags of broken trees with a height over $1.30 \mathrm{~m}$ and diameter at halfheight greater than or equal to $5.00 \mathrm{~cm}$ and (3) stumps not higher than $1.30 \mathrm{~m}$ and with a base diameter greater than or equal to $10.00 \mathrm{~cm}$. The degree or stage of decomposition was determined for each item of dead wood, using the classification of Maser et al. (1979) as modified by Bobiec et al. (2005). The degrees of decomposition in woody debris were 
described by Roman numerals and Arabic numerals referred to stages of decomposition in standing trees. Four stages of decomposition were distinguished in still-standing

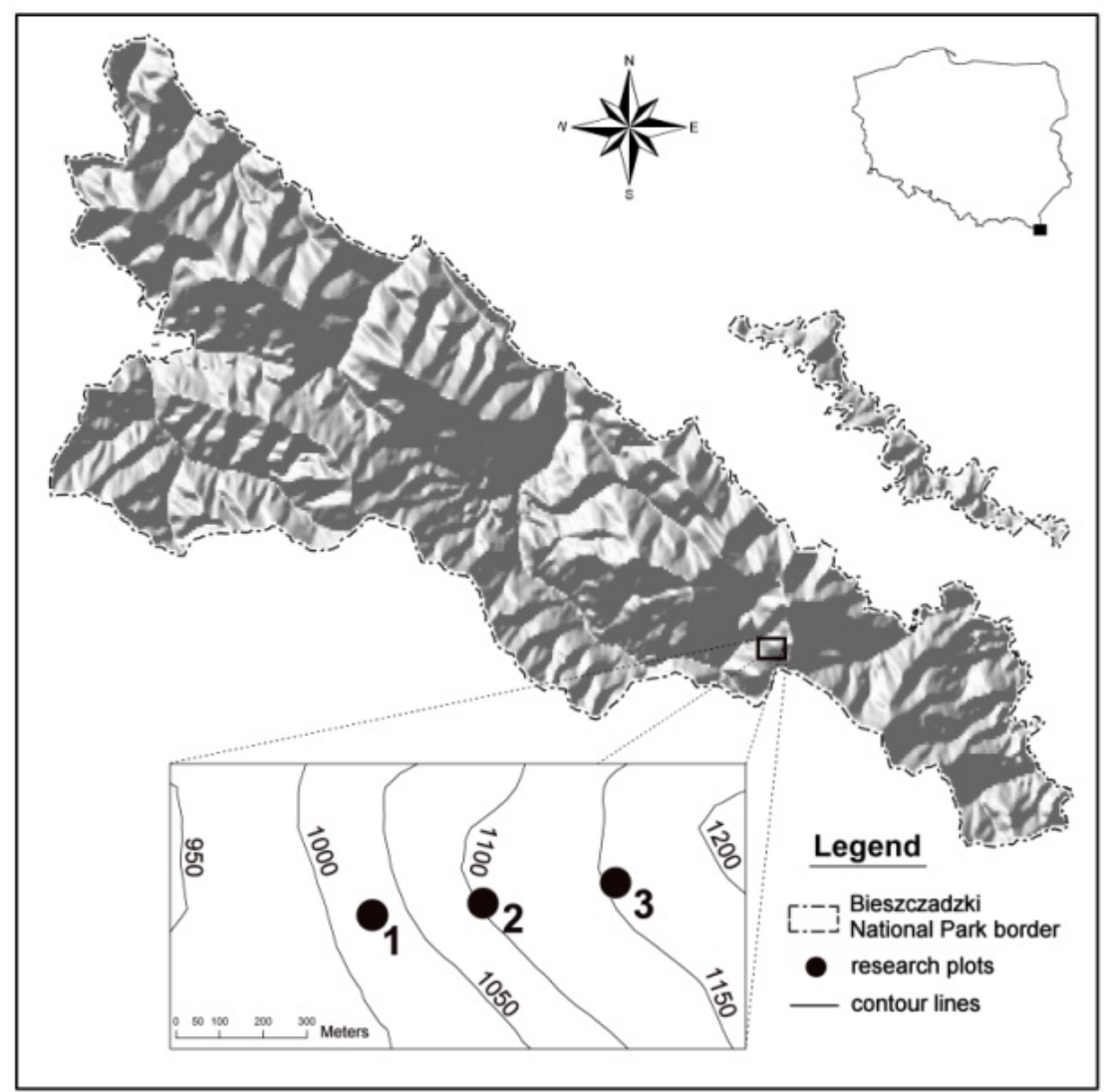

Figure 1. The location of the study area in the topography at the Bieszczady National Park

trees, and the coarse woody debris was evaluated using five degrees of decomposition (tab. 1). During the inventory of stumps, their height and diameter at the base was measured. For coarse woody debris, i.e., declining and broken trees, the height and thickness of the logs was measured at their halfheight. Halfheight-diameter measurements of lying trees were conducted only for the first three degrees of decomposition (1 - 3), whereas the length of coarse woody debris was measured for all distinguished degrees of decomposition. Diameter measurements were not performed on dead lying trees classified with degrees 4 and 5 of decomposition due to the flattening of their cross-section and fragmentation. There were 9 such trees in plot 1 , and in plots 2 and 3, there were 7 and 6 cases, respectively. At the same time, living trees with diameter at breast height greater than or equal to $5 \mathrm{~cm}$ were measured at each study plot. Diameter at breast height and height were measured for the trees that met the above criteria. The diameter of trees was measured with a circumeter with an accuracy of $0.1 \mathrm{~cm}$, and the height was determined with a Sunto altimeter, rounding the values to $0.1 \mathrm{~m}$. The share of trees at the study plots in various degrees of decomposition was calculated on the basis of length, with reference to the sum of the lengths of all pieces of coarse woody debris in each stage of decomposition. Coarse woody debris in which a great diversity of decomposition stages in different parts was observed was assigned the predominant degree of decomposition. However, when verifying the share of particular 
degrees of decomposition of standing trees, their thickness was taken into consideration. The thickness of dead trees was evaluated for all standing trees, and in coarse woody debris, only for trees representing the first three degrees of decomposition. Huber's equation was used to calculate the thickness of coarse woody debris (Bruchwald 1999). Only in one case, because of the preserved branches and relatively large dimensions of the dead standing tree, was thickness estimated based on Czuraj's tables of standing tree thickness (Czuraj et al. 1960). To determine the thickness of broken trees, snags and declining trees with very small dimensions, Huber's equation was also used. The thickness of living trees growing in the study plots was calculated using Denzin's equation (Czerepko 2008).

The Cartesian coordinates of all trees in the study plots were also identified during the study, adopting the centre of the plot as the origin. The coordinates of trees were used for graphical representation of their location in the field, which was prepared in a scale of 1:200 in AutoCad LT (test version 2010). On this basis, the type of spatial distribution in the study plots was determined for dead trees. The coordinates of butts were used as the reference points for the distribution of coarse woody debris.

The statistical and mathematical analysis used Ripley's $\mathrm{K}(\mathrm{t})$ function to determine the type of distribution of dead trees in the analysed stands (Szwagrzyk and Ptak 1991). Using Ripley's $\mathrm{K}(\mathrm{t})$ function, the distribution of distances between trees was compared with the ideally random model of distribution to assess whether the pattern was regular, random or clustered (Moeur 1997). In the performed analyses of spatial distribution of the objects on the plane, a modification of the $\mathrm{K}(\mathrm{t})$ function was applied in the transformed form of this function's estimator L(t). A Monte Carlo procedure and the method of determining the confidence intervals suggested by Mariott (Moeur 1997) were applied to determine the confidence levels. For this purpose, for the number of objects and the plots' area adopted in this study, a sufficient number of random arrangements (100 simulations) was generated, reaching a 95\% level of confidence. The above analyses of dead tree distribution in the plots were carried out using the Patar software package (Szwagrzyk and Ptak 1991).

The differences between the thicknesses of the dead trees in different study plots, due to the failure to meet the assumptions of parametric tests (the lack of normality distribution of the variable), were determined using the nonparametric equivalent of one-way ANOVA, i.e., using the Kruskal-Wallis test. The significance of differences was given for the $\alpha=0.05$ level of significance. The statistical analyses were carried out using the Statistica PL software package, version 9.01.

\section{Results}

A total of 50 dead trees were inventoried in the study plots. The greatest number $(\mathrm{n}=22)$ was found in plot 3 and the least $(\mathrm{n}=10)$ in plot 2 (tabs. 2 and 3). Coarse woody debris had the largest share, both quantitative and qualitative, among the distinguished forms of dead trees. In total, 34 dead lying trees $(68.0 \%$ of thickness of all dead trees) were found in the analysed area, which with the exception of one piece of wood, were all logs (tab. 2). Declining trees and whole dead standing trees prevailed quantitatively among dead standing trees. In terms of thickness, the highest values were related to snags of broken trees, whose share compared to the growing living trees reached $9.0 \%$ (tab. 2). 
Table 1. Degrees and stages of dead tree wood decomposition, including dead tree forms *

\begin{tabular}{|c|c|c|c|}
\hline \multicolumn{4}{|c|}{ Form of dead trees } \\
\hline \multicolumn{2}{|r|}{ Coarse woody debris } & \multicolumn{2}{|c|}{ Dead standing trees and stumps } \\
\hline Degree & Criteria for evaluation & Stage & Criteria for evaluation \\
\hline I & $\begin{array}{l}\text { Texture intact, circular, natural color } \\
\text { of wood, bark intact, branches }<3 \mathrm{~cm} \text {, } \\
\text { log leaning on branches }\end{array}$ & 1 & Tree dead for less than 1 year \\
\hline II & $\begin{array}{l}\text { Texture intact, circular, natural color } \\
\text { of wood, bark slightly damaged, no } \\
\text { branches }<3 \mathrm{~cm}, \log \text { begins to sink }\end{array}$ & 2 & Tree dead for $1-3$ years \\
\hline III & $\begin{array}{l}\text { Texture - larger hard fragments, } \\
\text { circular, faded color of wood, } \\
\text { fragmented bark, no branches }<3 \mathrm{~cm} \text {, } \\
\text { almost entire log on the ground }\end{array}$ & 3 & $\begin{array}{l}\text { Flaking bark, partial decomposition } \\
\text { of wood, lack of thinner branches }\end{array}$ \\
\hline IV & $\begin{array}{l}\text { Texture - small pieces, oval shape, } \\
\text { faded color of wood, no bark, no } \\
\text { branches }<3 \mathrm{~cm} \text {, entire log on the } \\
\text { ground }\end{array}$ & 4 & $\begin{array}{l}\text { No bark, advanced decomposition } \\
\text { of wood, no branches }\end{array}$ \\
\hline \multirow{2}{*}{$\mathrm{V}$} & \multirow{2}{*}{$\begin{array}{l}\text { Texture soft and loose, oval shape, } \\
\text { faded color of wood, no bark, no } \\
\text { branches }<3 \mathrm{~cm} \text {, entire on the ground }\end{array}$} & 5 & Strongly decomposed stump \\
\hline & & 6 & $\begin{array}{l}\text { Almost completely decomposed, } \\
\text { low stump }\end{array}$ \\
\hline
\end{tabular}

Table 2. Quantity and volume structure of various forms of dead trees inventoried in the study plots at the BdNP

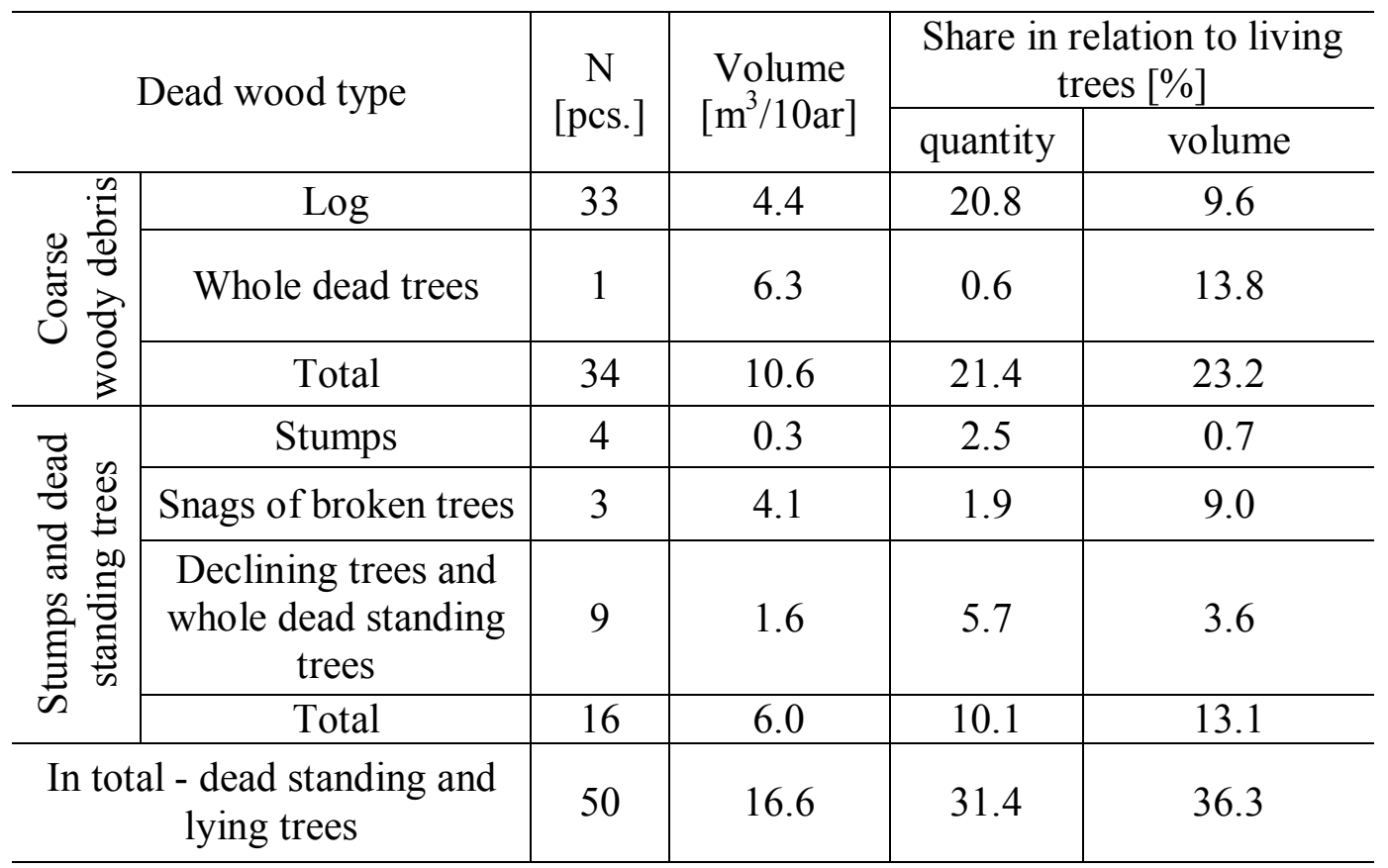

The average volume of the dead trees per hectare of the analysed plots was $55 \mathrm{~m}^{3}$ (tab. 3). In plot 1 , the volume of the coarse woody debris $\left(91.83 \mathrm{~m}^{3} / \mathrm{ha}\right)$ was over 10 times higher than the volume of the dead standing trees $\left(9.04 \mathrm{~m}^{3} / \mathrm{ha}\right)$. The opposite pattern was observed in the highest-situated plot (no. 3), where the coarse woody debris volume was $13.34 \mathrm{~m}^{3} /$ ha lower than the thickness of dead standing trees (tab. 3). The 
differences in the volumes of coarse wood debris and of dead standing trees between the study plots were statistically significant $(\mathrm{H}(2, \mathrm{~N}=40)=12.072, \mathrm{p}=0.0024$ for plots 1 and $3 ; p=0.0090$ for plots 2 and 3). In total, the share of different dead tree forms in the thickness of trees in the study plots ranged from $0.8 \%$ (plot 3 ) to $10.7 \%$ (plot 1 ) for the coarse woody debris. For the dead standing trees this share ranged from $1.04 \%$ in plot 1 to $13.2 \%$ in plot 2 (tab. 3).

Table 3. Volume $\left(\mathrm{m}^{3} / \mathrm{ha}\right)$ of coarse woody debris and dead standing trees and their percentage compared to living trees occurring in the study plots at the BdNP

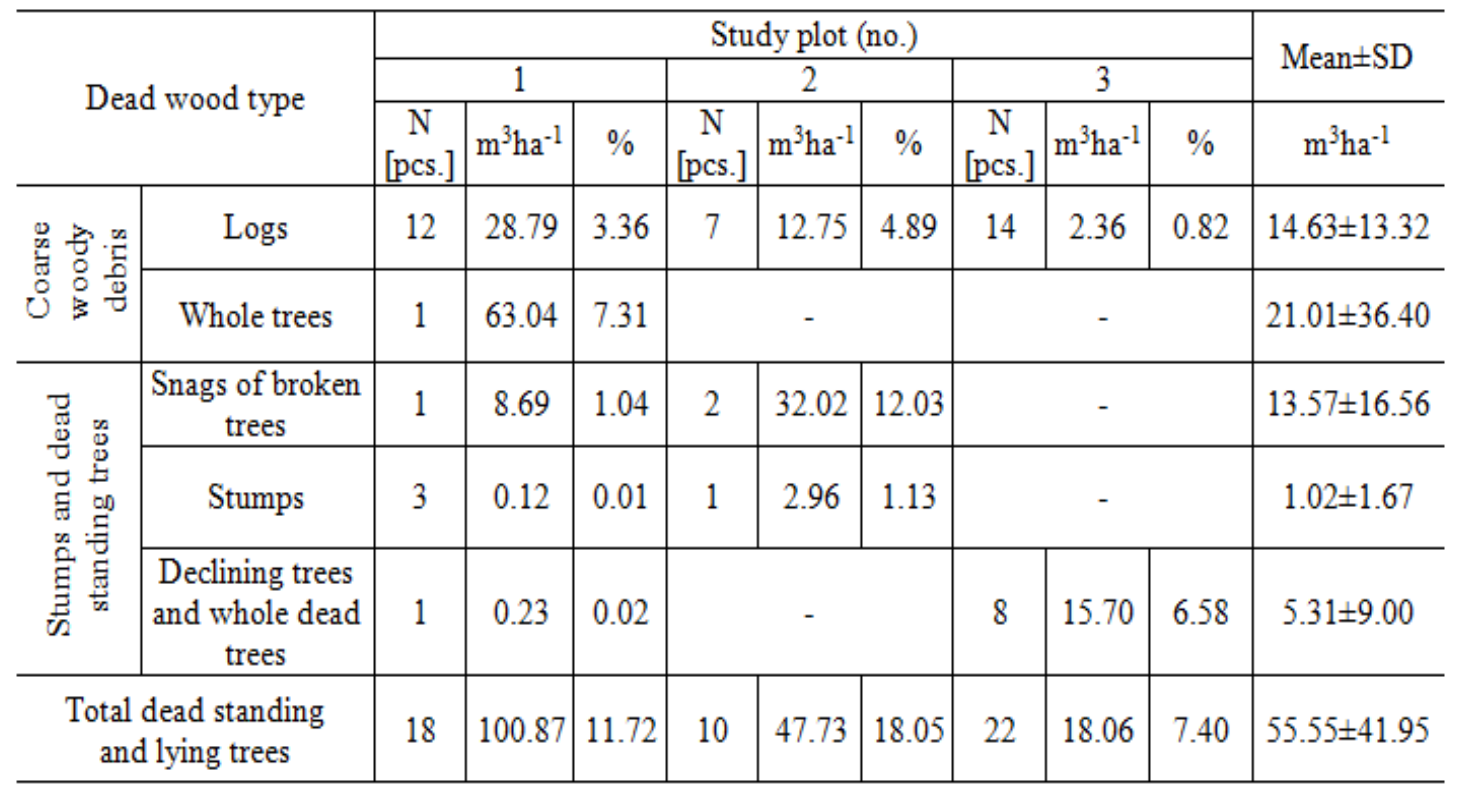

When analysing the size features of the examined trees in the stand in relation to the elevation above sea level, a downward trend of biometric parameters was demonstrated with increasing elevation, particularly with regard to the height of the trees (fig. 2 and $3)$. In plot 1 , there were 41 trees with diameter at breast height below $40 \mathrm{~cm}$ ( $2^{\text {nd }}$ class), representing $84.0 \%$ of all inventoried living trees. The share of trees with diameter at breast height over $40 \mathrm{~cm}$ in the total number of living trees in the plot reached $16.0 \%$ (fig. 2). Given the height, the predominance of trees below $25 \mathrm{~m}$ was observed (fig. 3). In the next two plots, the number of trees with DBH less than $40 \mathrm{~cm}$ increased and accounted for $74.0 \%$ of all inventoried living trees in plot 2 and $90.0 \%$ in plot 3 . At the same time, the height of the trees in plot 3 was the lowest of all the study plots (figs. 2 and 3).

The share of coarse woody debris and dead standing trees in various degrees and stages of decomposition was different in each study plot. In plots 1 and 3, the diversity of decomposition degrees of the coarse woody debris was significantly higher than of the dead standing trees (fig. $4 A$ and $B$ ). In both study areas, all degrees of decomposition of the coarse woody debris were recorded. The share of each degree of decomposition of the dead lying trees in plot 3 was similar and evenly distributed among the five degrees, whereas in plot 1 , the majority of coarse woody debris was in the II degree of decomposition (57.0\%) (fig. 4A). Almost all dead standing trees $(96.0 \%)$ were characterised by the $3^{\text {rd }}$ stage of decomposition, and this was observed in 
both study plots (fig. 4B). Relatively small differences in degrees and stages of decomposition of dead wood were observed in plot 2 . The highest shares, $80.0 \%$ of the coarse woody debris and $76.0 \%$ of the dead standing trees, were characterised by the IV degree and $4^{\text {th }}$ stage of decomposition (fig. $4 A$ and $B$ ).

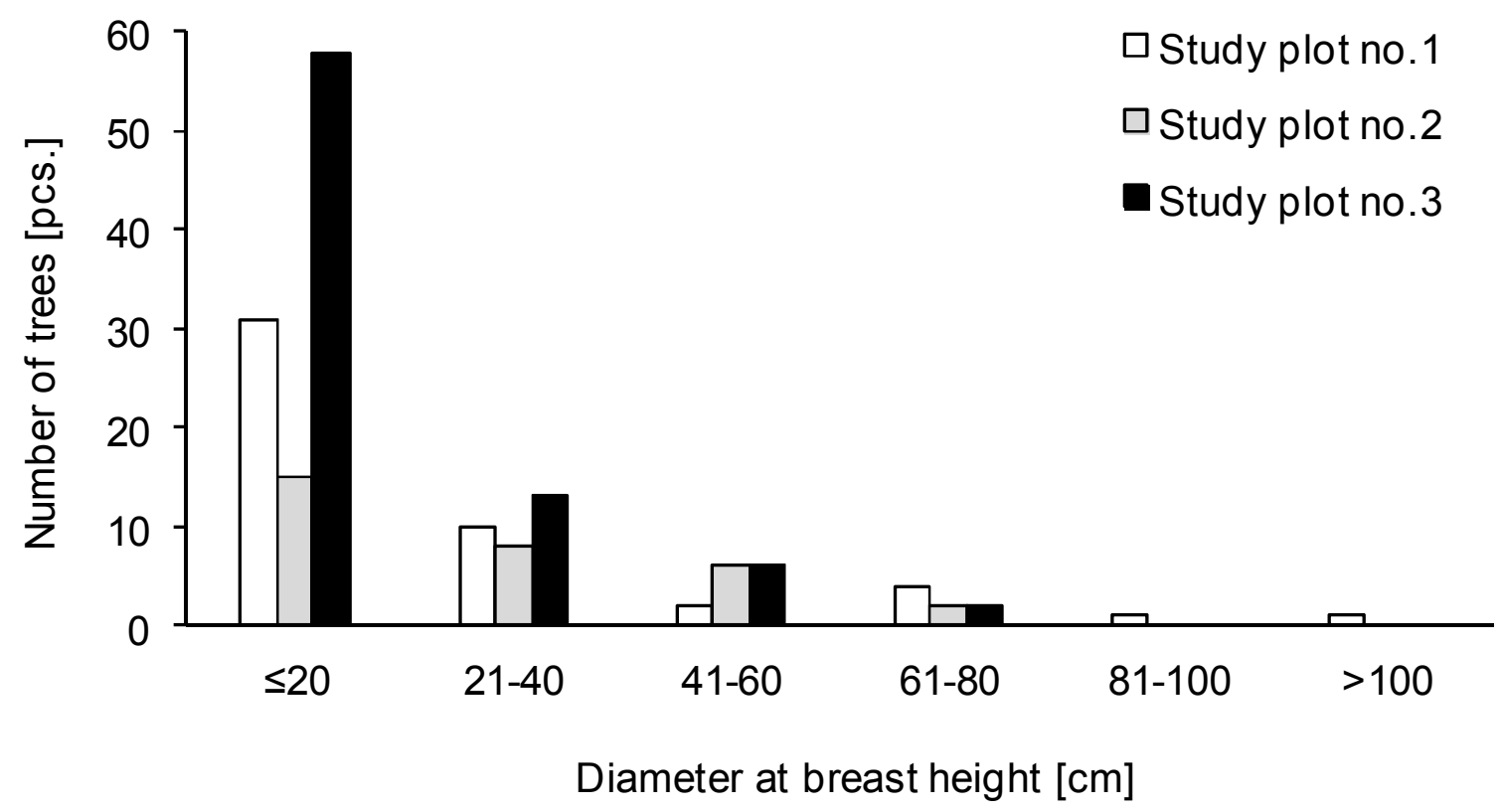

Figure 2. The structure of diameter at breast height of living trees in the study plots at the $\operatorname{BdNP}($ no. $1: n=49$, no. $2: n=31$, no. $3: n=79$ )

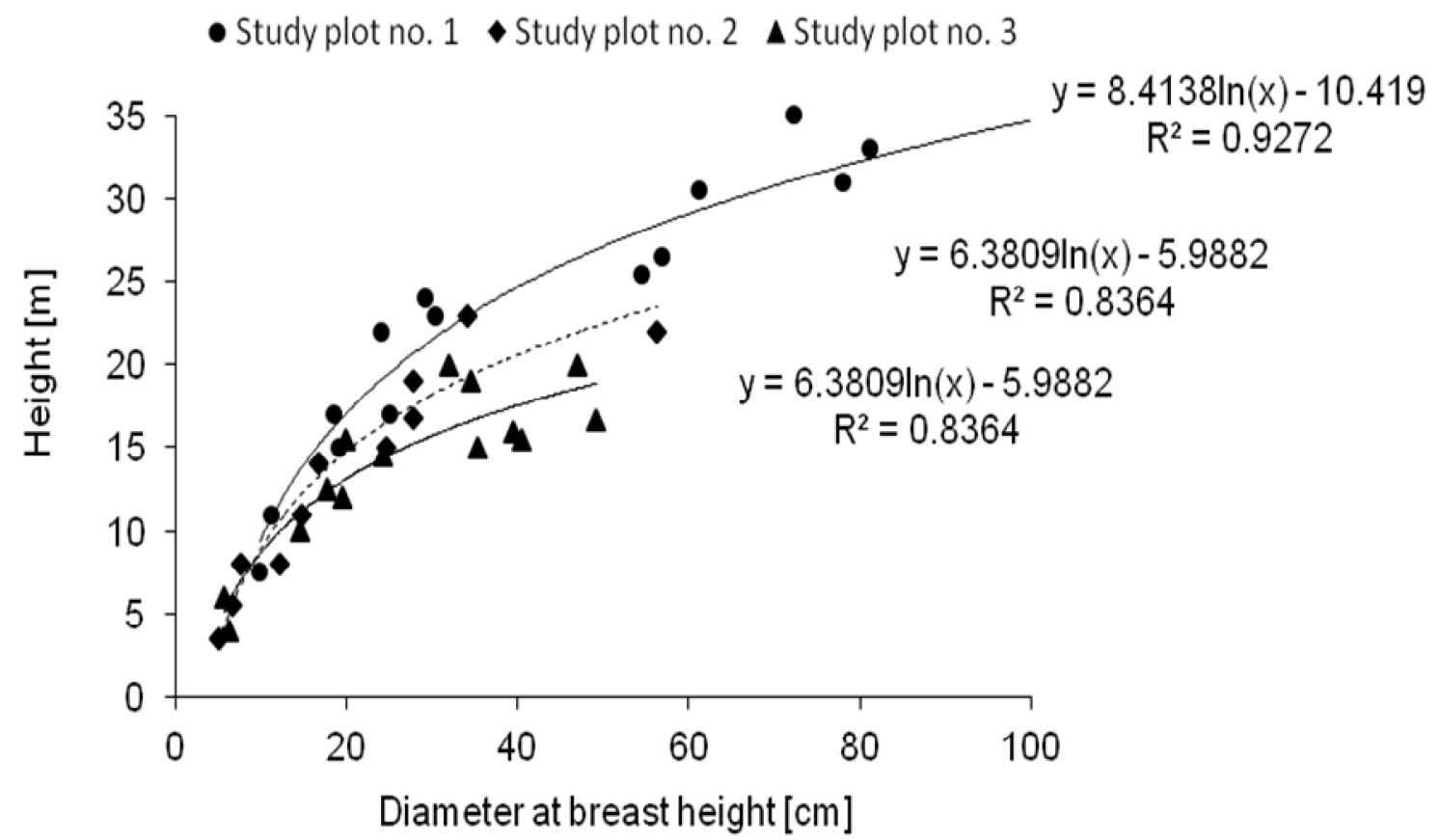

Figure 3. The curve of height of living trees growing in the study plots at the BdNP 

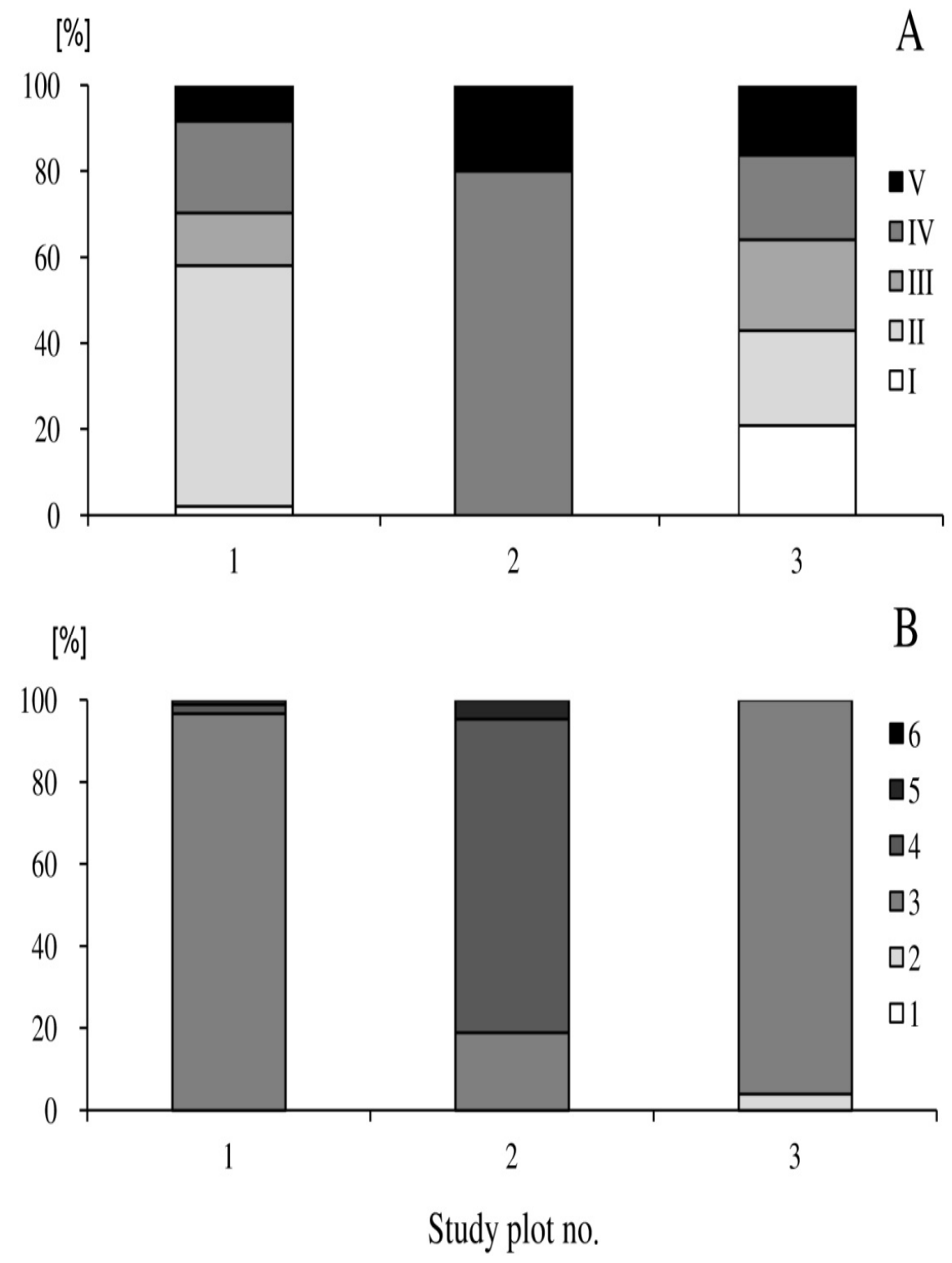

Figure 4. The percentage of degrees of coarse woody debris decomposition (A) and stages of dead standing trees decomposition (B) in the study plots at the BdNP

Spatial distribution patterns of dead standing and lying trees, determined using Ripley's $\mathrm{K}(\mathrm{t})$ function, differed in the various study plots. A regular distribution was found in the lowermost plot 1 (figs. $5 A, 6 A$ ), whereas in plot 2 (figs. $5 B, 6 B$ ) and plot 3 (the uppermost) (figs. 5C, 6C), the distribution of the dead trees in the stand was statistically significantly random and clustered, respectively.

The inventory of macrofungi carried out in the study plots found a total of 30 fungal species, which were most frequently affiliated with the order Agaricales. Plot 2, where 17 taxa were recorded, of which 10 occurred only in this particular plot, harboured the greatest diversity of macrofungal species. The smallest number of fungi associated with dead trees was found in plot 3. Nevertheless, 11 fungal species were identified, including 2 that occurred only in this particular plot (tab. 4). 

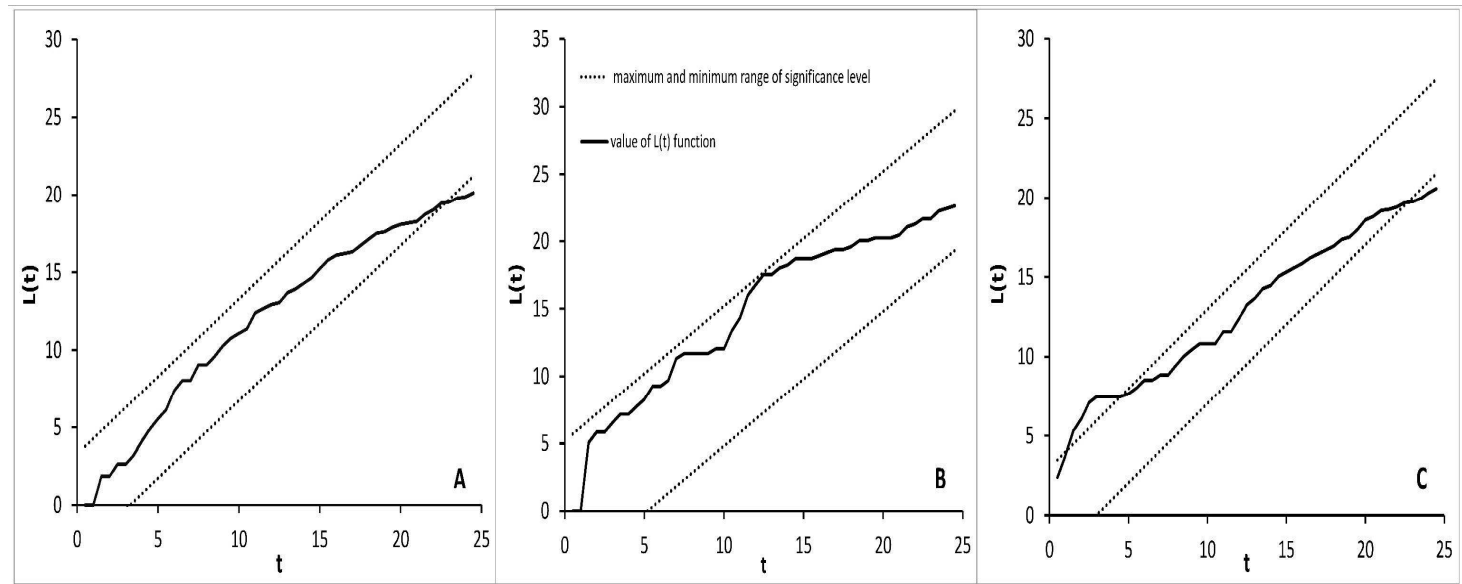

Figure 5. Diagrams of the $L(t)$ function for the distribution of dead trees in beech forest localised at Rozsypaniec slope at the Bieszczady National Park (A-study plot no. 1 at 1035 m.a.s.l. - regular tree distribution, B- study plot no. 2 at 1091 m.a.s.l. - random tree distribution, C-study plot no. 3 at 1146 m.a.s.l.- clustered tree distribution)

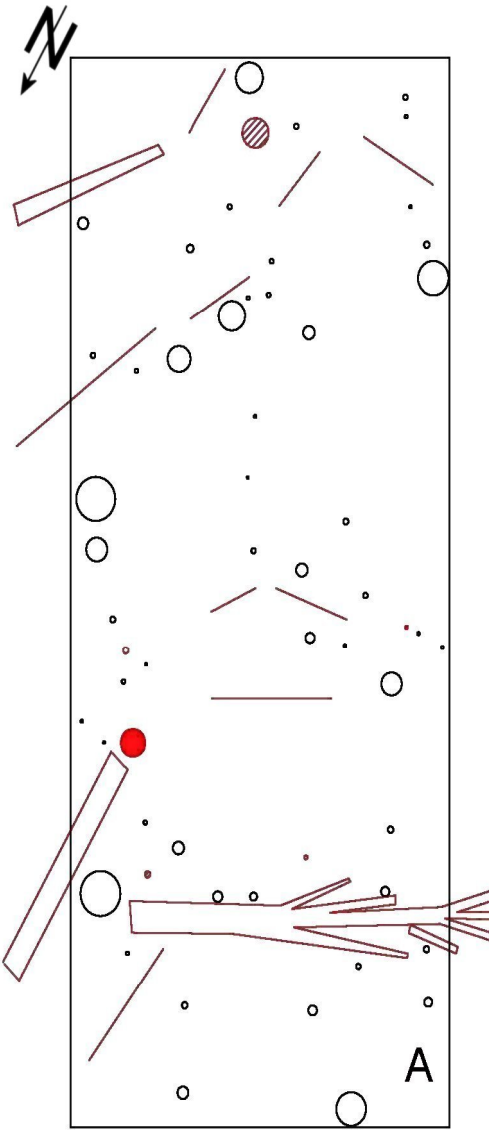

. Skale 1: 200

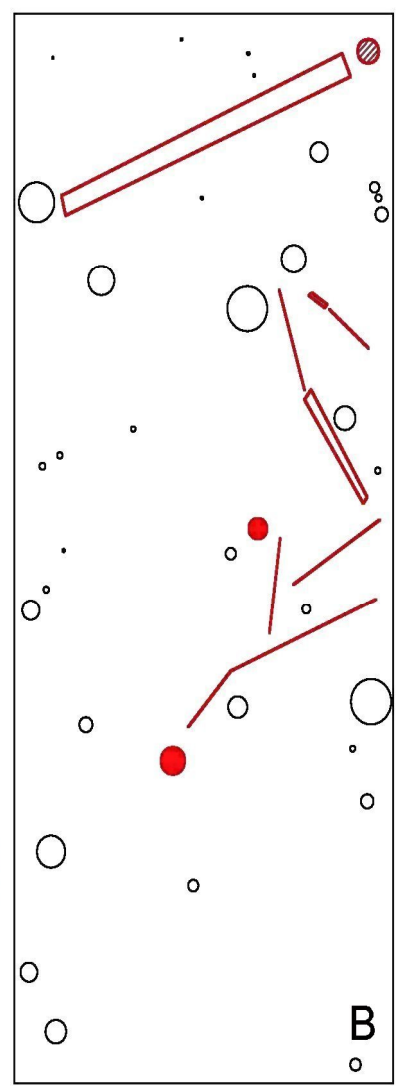

Legend

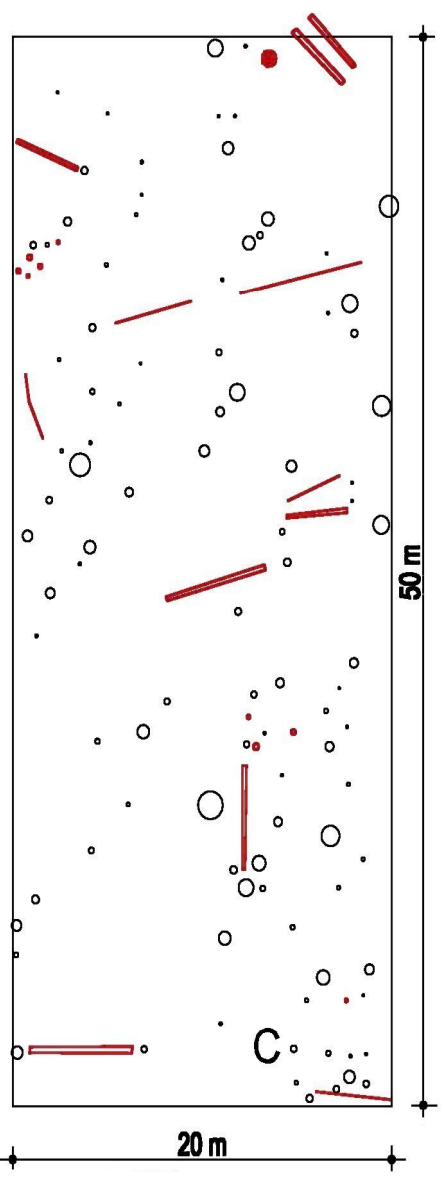

DBH cross-section of living tree

whole dead standing tree

standing declining tree

snag of broken tree

coarse woody debris in I, II or III degree of decomposition $\backslash$ coarse woody debris in IV or V degree of decomposition stump

Figure 6. Horizontal projection of living and dead tree stumps and their arrangement in the study plots at the BdNP (A - study plot no. 1, at 1035 m.a.s.l., B -study plot no. 2, at $1091 \mathrm{~m}$ a.s.l., $C$ - study plot no. 3, at $1146 \mathrm{~m}$ a.s.l.) 
Table 4. List and frequency* (\%) of macrofungi associated with coarse woody debris and dead standing trees in the study plots at the BdNP

\begin{tabular}{|c|c|c|c|c|}
\hline \multirow{2}{*}{$\begin{array}{c}\text { Species name } \\
\left({ }^{* *} \text { Red List species: } \mathrm{R}, \text { rare, E, endangered }\right)\end{array}$} & \multicolumn{3}{|c|}{ Study plot (no.) } & \multirow{2}{*}{$\begin{array}{l}\text { Area in } \\
\text { total }\end{array}$} \\
\hline & 1 & 2 & 3 & \\
\hline \multicolumn{5}{|l|}{ Basidiomycota, Agaricales } \\
\hline Megacollybia platyphylla (Pers.) Kotl. \& Pouzar & 5.5 & - & - & 2 \\
\hline Pluteus aurantiorugosus (Trog) Sacc & 5.5 & - & - & 2 \\
\hline $\begin{array}{l}\text { Phaeomarasmius erinaceus (Fr.) Scherff. ex } \\
\text { Romagn.* }^{*}(\mathrm{R})\end{array}$ & 5.5 & - & - & 2 \\
\hline Pleurotus ostreatus (Jacq.) P. Kumm. & 5.5 & - & - & 2 \\
\hline Lycoperdon pyriforme Schaeff. & 5.5 & 10 & - & 4 \\
\hline Lycoperdon perlatum Pers. & - & 20 & - & 4 \\
\hline Mycena flavescens $\mathrm{Vel}^{* *}(\mathrm{R})$ & - & 10 & - & 2 \\
\hline Psathyrella sp.(Fr.) Quél & - & 10 & - & 2 \\
\hline Marasmius alliaceus (Jacq.) Fr. & - & 20 & 14 & 10 \\
\hline Pluteus nanus (Pers.) P. Kumm. & - & 10 & - & 2 \\
\hline Mycena haematopus (Pers.) P. Kumm. & 5.5 & 10 & - & 4 \\
\hline Pseudoclitocybe cyathiformis (Bull.) Singer & - & 10 & - & 2 \\
\hline Oudemansiella mucida (Schrad.) Höhn. & 5.5 & 10 & 9.1 & 8 \\
\hline Crepidotus sp. (Fr.) Staude & - & - & 4.5 & 2 \\
\hline Armillaria sp. (rhizomorphs) (Fr.) Staude & 5.5 & 30 & 4.5 & 10 \\
\hline \multicolumn{5}{|l|}{ Basidiomycota, Polyporales } \\
\hline Ganoderma applanatum (Pers.) Pat. & 16.7 & - & - & 6 \\
\hline Fomitopsis pinicola (Sw.) P. Karst. & 5.5 & - & 9 & 6 \\
\hline Steccherinum ochraceum (Pers.) Gray & - & 10 & - & 2 \\
\hline Mycoacia aurea (Fr.) Erikss \& Ryw. ${ }^{* *}$ (E) & - & 10 & - & 2 \\
\hline Fomes fomentarius (L.) Fr. & 22 & 30 & 32 & 28 \\
\hline Phlebia livida (Fr.) Bres. ${ }^{* *}(\mathrm{E})$ & - & 10 & - & 2 \\
\hline Phanerochaete laevis (Pers.:Fr.) Erikss Ryv. & - & - & 4.5 & 2 \\
\hline \multicolumn{5}{|l|}{ Basidiomycota, Russulales } \\
\hline Stereum hirsutum (Willd.) Pers. & 17 & 20 & 14 & 16 \\
\hline \multicolumn{5}{|l|}{ Ascomycota, Xylariales } \\
\hline Eutypa spinosa (Pers.) Tul. \& C. Tul. & 5.5 & - & - & 2 \\
\hline Hypoxylon sp. Adans. & - & 10 & - & 2 \\
\hline Hypoxylon fragiforme (Pers.) J. Kickx f. & - & 10 & - & 2 \\
\hline Hypoxylon cohaerens (Pers.) Fr. & - & - & 14 & 6 \\
\hline Xylaria longipes Nitschke & 17 & - & 4.5 & 8 \\
\hline \multicolumn{5}{|l|}{ Ascomycota, Helotiales } \\
\hline Bisporella citrina (Batsch) Korf \& S.E. Carp. & - & 20 & 9.1 & 8 \\
\hline \multicolumn{5}{|l|}{ Ascomycota, Pezizales } \\
\hline Scutellinia sp. (Cooke) Lambotte & 5.5 & - & - & 2 \\
\hline
\end{tabular}

\footnotetext{
*The frequency was expressed as the percentage of dead wood with a given fungal species in the total
} number of analysed dead wood 
The species Fomes fomentarius (L.) Fr. was the most frequently recorded (28.0\%) and was identified 4 times $(22.0 \%)$ in plot 1,3 times $(30.0 \%)$ in plot 2 and 7 times (32.0\%) in plot 3. Stereum hirsutum (Willd.) Pers. (16.0\%), Marasmuis alliaceus (Jacq.) Fr. (10.0\%) and Honey fungi Armillaria sp. (Fr.) Staude (10.0\%) were also frequently observed fungal species. The occurrence of other fungal species was occasional (tab. 4). Among the inventoried fungal species, four taxa, viz. Phaeomarasmius erinaceus (Fr.) Scherff. ex Romagn. (R) (Pic. 1A), Phlebia livida (Pers.) Bres (Pic. 1B), Mycena flavescens Vel. (Pic. 1C) and Mycoacia aurea (Fr.) Erikss \& Ryw. (Pic. 1D), were identified as included in the IUCN Red List of Threatened Species. It was demonstrated that significantly more fungi occurred on dead lying trees $(77.3 \%)$ than on standing trees $(10.7 \%)$. In terms of degree and stage of decomposition of the analysed material, the greatest abundance of macrofungal species was observed on the coarse woody debris in the IV degree of decomposition, in the $5^{\text {th }}$ stage of decomposition on stumps, and in the $3^{\text {rd }}$ stage of decomposition on the remaining forms of dead standing trees (tab. 5).

Table 5. Frequency (\%) of macrofungi on dead standing and lying trees depending on the degree and stage of decomposition in study plots at the BdNP

\begin{tabular}{|c|c|c|c|c|c|c|c|c|}
\hline \multicolumn{2}{|c|}{ Dead wood type } & I & II & III & IV & \multicolumn{2}{|c|}{ V } & $\begin{array}{c}\text { In total } \\
\text { degrees I - } \\
\mathrm{V}\end{array}$ \\
\hline \multirow{2}{*}{ 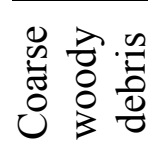 } & $\log s$ & 3.4 & 17.2 & 25.9 & 41.4 & \multicolumn{2}{|c|}{12.1} & 77.3 \\
\hline & (8) Whole trees & - & 100.0 & - & - & \multicolumn{2}{|c|}{-} & 10.7 \\
\hline \multicolumn{2}{|c|}{ Dead wood type } & 1 & 2 & 3 & 4 & 5 & 6 & $\begin{array}{l}\text { In total } \\
\text { stages } \\
1-6\end{array}$ \\
\hline \multirow{3}{*}{ 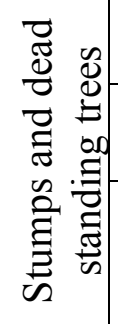 } & Stumps & - & - & - & - & 100.0 & - & 1.3 \\
\hline & $\begin{array}{c}\text { Snags of broken } \\
\text { trees }\end{array}$ & - & - & 66.7 & 33.3 & - & - & 4.0 \\
\hline & $\begin{array}{c}\text { Declining trees } \\
\text { and whole dead } \\
\text { trees }\end{array}$ & - & 40.0 & 60.0 & - & - & - & 6.7 \\
\hline
\end{tabular}

\section{Discussion}

The occurrence of dead trees in forest ecosystems is one of the most important indicators of environmental biodiversity conservation (Stevens 1997, Czerepko 2008, Müller and Bütler 2010). Competition and disturbances caused by biotic and abiotic factors are fundamental processes in forest biocenoses responsible for the presence of dead trees in the stand. The intensity of self-thinning processes is also largely a 
derivative of the habitat's fertility and the species composition of the stand (Solon and Wolski 2002, Gutowski et al. 2004, Holeksa and Maciejewski 2006). Leaving dying trees in coniferous stands, particularly spruce stands, favours the massive occurrence of cambio- and xylophagous insects, whereas in deciduous forests, increasing the amount of coarse woody debris and dead standing trees does not significantly affect the emergence and development of secondary pests (Stevens 1997, Köster et al. 2004, Starzyk et al. 2008). The count and volume share of dead trees in the stands is also affected by forest management and functions of stands (Wolski 2002). A relatively small abundance of dead trees in managed forests is usual when compared with forests under protective status (Dudley and Vallauri 2005, Czerepko 2008). In forests with nonproduction functions related to the conservation of natural environment, the presence of dead standing and lying trees is positively correlated with the term of their protection. The highest abundance of dead trees (on average $220 \mathrm{~m}^{3} / \mathrm{ha}$ ) is observed in montane forests, in solid and mixed beech stands under strict protection for more than 50 years, whereas lower values $\left(117 \mathrm{~m}^{3} / \mathrm{ha}\right)$ are observed in stands under protection for shorter time (Christensen et al. 2005). Yet even as a deficiency of dead standing and dying trees is unfavourable for the maintenance and improvement of environmental biodiversity (Müller and Bütler 2010), their excessive accumulation in the forest, i.e., over $60.0 \%$ of living tree volume, is also undesirable. The excessive share of dead matter may lead to environmental biocenotic imbalances and the consequent decay of tree stands (Jankovský et al. 2004b, Pasierbek et al. 2007). The presence of dead trees in the forest is modulated by the spatiotemporal variability of factors structuring their occurrence. Thus, there are significant differences in the amount of dead trees in various regions and forest complexes. The thickness of dead trees in reserves ranges from $27.6 \mathrm{~m}^{3} / \mathrm{ha}$ (Karula reserve) and $48.53 \mathrm{~m}^{3} /$ ha (Lahemaa reserve) in Estonia, through $107.3 \mathrm{~m}^{3} / \mathrm{ha}$ (Lang-Leitn reserve) in Austria, to $132 \mathrm{~m}^{3} /$ ha (Knéhyné-Certův mlyn reserve) in the Czech Republic (Jankovský et al. 2004b, Köster et al. 2004, Rahman et al. 2008). On the other hand, the thickness of coarse woody debris and dead standing trees in the area of the Białowieża Forest ranges from 87 to $392 \mathrm{~m}^{3} / \mathrm{ha}$, and in the area of Seiteseminen National Park in Finland, the dead matter resources range from 100 to $232 \mathrm{~m}^{3} / \mathrm{ha}$ (Nilsson et al. 2003, Dudley and Vallauri 2005). The differences in the number of dead trees remaining in tree stands are also determined by the species composition of the stands. It is estimated that in Europe, the average thickness of dead lying and standing trees in reserves with predominance of beech reaches $130 \mathrm{~m}^{3} /$ ha and 20 to $70 \mathrm{~m}^{3} / \mathrm{ha}$ in central Europe (Müller and Bütler 2010). In Poland, however, the average thickness of dead matter in beech stands is $9.6 \mathrm{~m}^{3} /$ ha, ranging from 0 to $298 \mathrm{~m}^{3} /$ ha (Czerepko 2008). Among the common forest types in the country, the highest average abundance of dead trees (over $42 \mathrm{~m}^{3} / \mathrm{ha}$ ) is observed in mountain beech stands. Similarly, in Central Europe the majority of studies on the amount of dead trees in forest biocenoses concern beech stands (Kraigher et al. 2002, Christensen et al. 2005, Ekbom et al. 2006, Oheimb et al. 2006, Müller and Bütler 2010). The studies carried out in the stands of the Bieszczady National Park indicate that the average thickness of dead standing and lying trees in the stands of the Rozsypaniec massif is $55.5 \mathrm{~m}^{3} /$ ha. This places the discussed stands significantly above the average thickness of dead trees, both in the country and in the Carpathian land itself (Czerepko 2008). Nevertheless, the thickness of dead trees was significantly different between the study plots, as a decrease in thickness of dead matter was observed with increasing elevation above sea level. In the lowermost plot the thickness of the coarse woody debris and the dead standing trees was six times greater 
than the thickness of the dead trees inventoried in the uppermost plot. The decrease in the thickness of dead lying and standing trees together with the increasing elevation above sea level is most likely related to the biometric parameters of living trees in the study plots. According to Stevens (1997), Szymański (2000) and Holeksa and Maciejewski (2006), the biometric parameters of trees in the stand have a significant effect on the amount of dead trees. There is a close relationship between the increase in size of standing trees and the thickness of coarse woody debris. Therefore, in the stand located the nearest to the top treeline, characterised by inhibited growth in height and thickness, the thickness of various forms of dead tree-wood was relatively small. The abundance of dead trees is not the only important information about the biological diversity of the environment. The form, arrangement and decomposition rate of the dead matter are also important from the point of view of preferences of various organisms that use dead trees (Piotrowski and Wołk 1975, Stevens 1997, Gutowski et al. 2004). The presence of dead wood of a certain shape and size is crucial for the survival of numerous endangered species (Piotrowski and Wołki 1975, Solon and Wolski 2002, Gutowski et al. 2004, Gutowski 2006). Woodpeckers (Picinae) are one of the examples, for whom the presence of dead standing trees in the forest is often essential for finding food, shelter and nesting (Ciach 2011). On the other hand, coarse woody debris, due to its ability to retain moisture, is the site for the growth of mosses, liverworts and fungi (Piotrowski and Wołk 1975, Stevens 1997, Solon and Wolski 2002, Gutowski et al. 2004). According to Christensen et al. (2005), coarse woody debris contributes greatly to the thickness of dead trees in European beech stands. The average thickness of coarse woody debris is almost three times greater than the thickness of dead standing trees. In montane forests, characterised by greater abundance of dead standing trees compared to lowland and foothills forests, there is almost twice as much coarse woody debris. Tree stumps, followed by coarse woody debris, are the most common types of dead trees in Polish forests, whereas whole lying trees, standing declining trees and whole standing trees are least common (Czerepko 2008). It is estimated that the average thickness of lying trees is $4.2 \mathrm{~m}^{3} / \mathrm{ha}\left(\operatorname{logs}: 4 \mathrm{~m}^{3} / \mathrm{ha}\right.$, whole dead lying trees: $\left.0.2 \mathrm{~m}^{3} / \mathrm{ha}\right)$, whereas the average thickness of dead standing trees reaches $5.4 \mathrm{~m}^{3} /$ ha (stumps: $2.6 \mathrm{~m}^{3} /$ ha, standing declining trees: $0.8 \mathrm{~m}^{3} /$ ha, whole dead standing trees: $2.1 \mathrm{~m}^{3} / \mathrm{ha}$ ). When analysing the share of various forms of dead trees in the total volume of dead matter of the Carpathian land, it was found that logs account for the most volume $\left(18.76 \mathrm{~m}^{3} / \mathrm{ha}\right)$. The other forms of dead standing and lying trees, such as stumps, standing declining trees, whole dead standing trees or whole dead lying trees reach significantly smaller thickness: 5.85 $\mathrm{m}^{3} /$ ha, $5.1 \mathrm{~m}^{3} /$ ha respectively, which constitutes $54.6 \%$ of the thickness of all dead trees (Czerepko 2008).

The study carried out in 2011 in beech stands, located on the hillsides of the Rozsypaniec mount, proves that the amount of the coarse woody debris outweighs the amount of the dead standing trees, but in this case the differences between the volumes of the discussed forms of dead wood were significantly greater $(16.10 \%)$. Moreover, the volume share of the distinguished forms of dead trees differed between the study plots. The coarse woody debris clearly dominated in the lowermost plot $1(91 \%$ share of the volume compared to the remaining forms of dead trees). In the next two stands (plots 2 and 3), this proportion was reversed, in favour of dead standing trees, representing $73 \%$ and $87 \%$ of the thickness of inventoried dead trees in plot no. 2 and uppermost plot, respectively. According to Christensen et al. (2005), the double prevalence of dead standing trees in the total dead matter accumulated in mountain beech stands over the 
lowland and foothills beech forests results from the presence of spruce and fir in the former stands. Coniferous trees are more susceptible than deciduous trees to damages and dieback caused by insect feeding, which is the primary causal agent of standing deadwood. Picea abies (L.) Karst is highly susceptible to damage caused by cambioand xylophagous insects, especially by the European spruce bark beetle (Ips typographus L.) (Coleoptera, Scolytinae) (Kuś and Kuś 2004; Starzyk et al. 2008). Moreover, standing declining trees of coniferous species remain longer in the stand, and their decomposition is also slower than that of deciduous trees (Christensen et al. 2005, Ekbom et al. 2006, Holeksa and Maciejewski 2009).

Taking into consideration the distribution of dead trees in the study plots, it was observed that elevation was a crucial factor for the spatial distribution of dead trees. The lowermost stands were characterised by regular or random distribution of dead matter, and in the uppermost beech stands, clustered distribution of dead trees was observed. Trees growing in harsh mountain conditions, located close to the top treeline, produce the so-called biogroups through contact with each other and by their root systems growing together (Rigg and Harrar 1931, Graham and Bormann 1966, Loehle and Jones 1990, Karaś 1995). The clustered distribution of dead trees in the uppermost study plot indicates the collective nature of tree life, which results in their self-thinning during the dieback. This phenomenon seems to be crucial to ensure adequate living conditions for various groups of organisms with specialised ecological requirements and for the evolution of microhabitats.
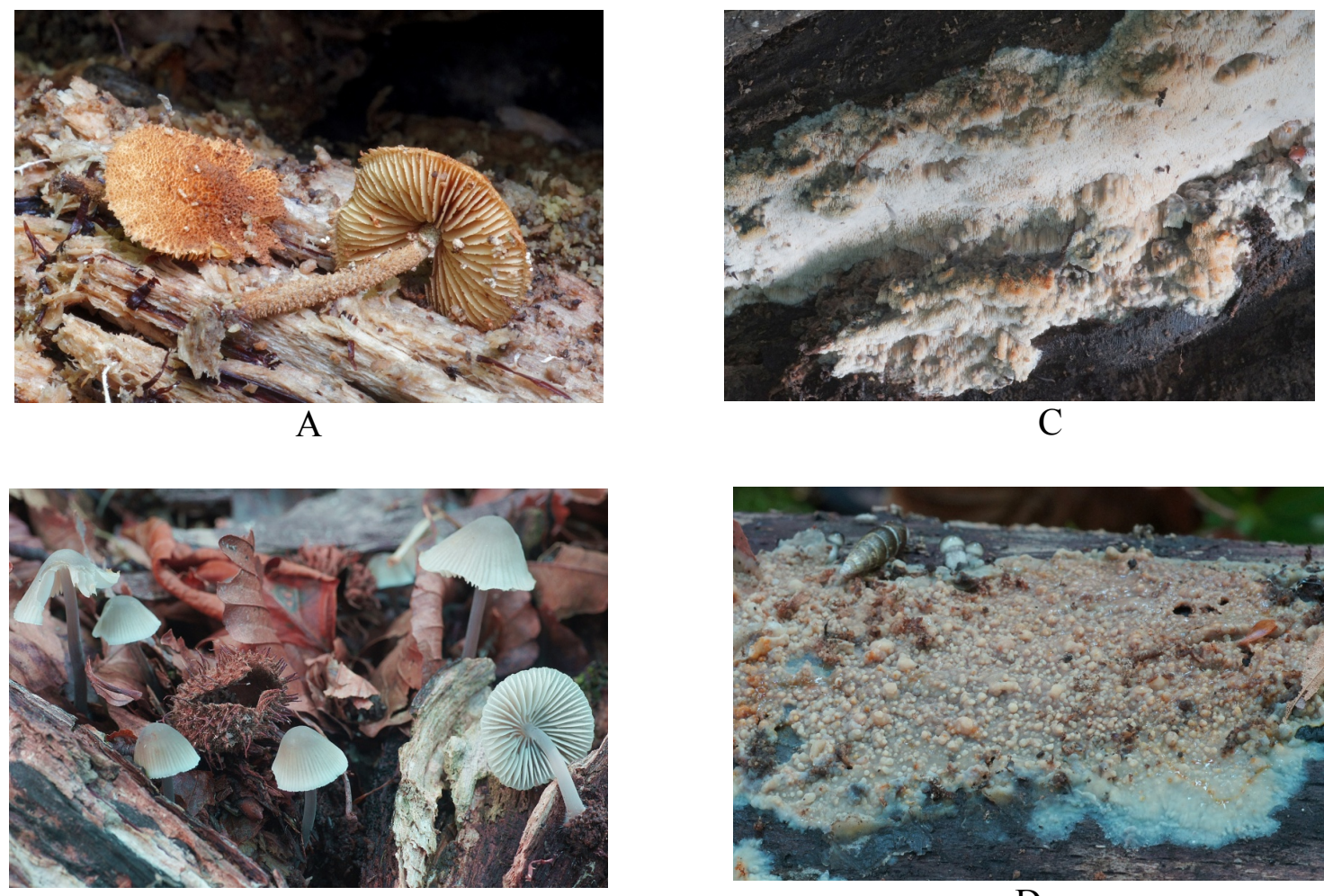

B

$\mathrm{D}$

Picture 1. The occurrence of macromycete fungi on European beech dead wood in the Rozsypaniec massif at the Bieszczady National Park (A - Phaeomarasmius erinaceus (Fr.) Scherff. Ex Romagn; B - Phlebia livida (Pers.) Bres; C-Mycena flavescens Vel.; D - Mycoacia aurea (Fr.) Erikss \& Ryw.), (photos by Bolestaw Kuźnik, August, 2011) 
The biodiversity of the environment is also determined by the degree of decomposition of dead trees. On one hand, due to the release of organic matter content, the decomposing wood of dead trees is important for nutrient cycling. On the other hand, decomposing wood affects vital functions of trees. The rate of decomposition of dead trees depends on the species and parameters of trees and on prevailing climatic conditions (Holeksa and Maciejewski 2009, Müller-Using and Bartsch 2009). A faster rate of decomposition of dead coarse woody debris and smaller standing trees is recorded in warm and humid climates and during frost (Stevens 1997). Tree decomposition may take from several to even a few hundred years (Gutowski et al. 2004). In lower subalpine deciduous stands growing in the Carpathians from 600 to $1200 \mathrm{~m}$ above sea level, dead tree decomposition lasts from several years to several decades (Holeksa and Maciejweski 2009). With the progressive decomposition of dead trees, their structure, wood colour and bark cover, and thereby the occurrence of accompanying organisms, are all changed (Solon and Wolski 2002, Gutowski et al. 2004, Pasierbek et al. 2007, Czerepko 2008). In Polish stands, the majority of coarse woody debris is in the III stage of decomposition (29.5\%) (Holeksa and Maciejweski 2009). All dead lying and standing trees in the reserves are mainly in the I and II degrees of decomposition, whereas the stumps are in degrees IV and V (Pasierbek et al. 2007). On the other hand, the majority of dead standing trees and coarse woody debris in the beech stands of the BdNP were in the IV stage and $4^{\text {th }}$ degree of decomposition, i.e., the structure of the trees was heavily compromised. The accumulation of trees in the IV degree and $4^{\text {th }}$ stage of decomposition may indicate a relatively slow process of organic matter decomposition on the mountainsides of the Rozsypaniec massif. The slow process of dead trees' decomposition leads to the long-term dynamic succession of microhabitat conditions, followed by the succession of organisms. It is estimated that a single tree, from the moment of death to complete decomposition, is inhabited by several to hundreds of species of mosses, liverworts, fungi, plants and insects. Currently, due to the insufficient number and small diversity of dead trees in forests, the previously mentioned groups of organisms are among the most endangered species. Forest fragmentation, preventing the even distribution of dead trees, is a major barrier to spreading of many saproxylobiontic species (Stevens 1997, Gutowski 2006).

Among numerous organisms occurring on dead trees, fungi play the most important role in the decomposition of dead matter. Wood infested by fungi may in fact contain approximately 1.5 times more nitrogen and water than those devoid of fungi. Fungi also secrete substances (carbohydrates, proteins and acids) that are used by other organisms for vital functions (Gutowski et al. 2004, Jankovský et al. 2004a, Holeksa and Maciejewski 2006). The species from families of bracket fungi (Poliporaceae) and corticoid fungi (Corticiaceae) are the most common groups occurring on dead trees and causing their decomposition (Olsson 2008). Detailed studies on the species diversity of fungi associated with dead trees in beech stands were carried out in Denmark, Belgium, Slovenia, the Netherlands and Hungary, inventorying a total of 457 fungal taxa. The greatest species diversity was observed in Belgium and Denmark, and the largest share of protected species was detected in Hungary and Slovenia (Ódor et al. 2006). In the Czech Republic, Jankovský et al. (2004a), by examining the mycoflora of dead standing and lying trees in the Vélky Polom and Želazné Hory reserves, observed the presence of 220 fungal species, including saprotrophs living on the decomposed wood of dead trees. Eighty-four species of fungi occurring on small wood pieces of barkless trees, 142 species on the bark of coarse woody debris, 282 species on stumps and 10 species on 
declining trees were found in the hornbeam forests of Białowieża National Park (Gutowski et al. 2004). So far, 1054 fungal species have been reported in Bieszczady National Park, of which 146 occur in rare sites in Poland and 85 occur only in the Park. The occurrence of 30 macrofungi species was observed in the inventoried study plots in the BdNP. According to the valuation of fungi, based on the number of positions, degree of risk of extinction and their origin (Kujawa 2011), the majority of the recorded species belonged to the IV category, which is the average value. The observed diversity includes such species as yellow fairy cups (Bisporella citrina (Batsch) Korf. \& Et. S. E. Carp.), Hypoxylon fragiforme (Perst.) J. Kickx f., tinder fungus (Fomes fomentarius (L.) Fr.), red banded polypore (Fomitopsis pinicola (Sw.) P. Karst.), and Oudemansiella mucida (Schrad.) Höhn. The only species with high value (category III) found in the study plots was Hypoxylon cohaerens (Pers.) Fr. Interestingly, the presence of species characterised by a very high value was recorded (category II) - Phaeomarasmius erinaceus (Fr.) Scherff. ex Romagn. (R), Phlebia livida (Pers.) Bres and Mycena flavescens Vel. These fungal species are on the red list of threatened species (Wojewoda and Lawrynowicz 2006).

\section{Conclusions}

The research indicates that there is a relationship between elevation and the amount and form of dead wood in the beech stands of Bieszczady National Park. The share of dead standing trees compared to coarse woody debris increased when approaching the top treeline, while the thickness of both living and dead trees decreased. The high average amount of dead matter in the beech stands of the Rozsypaniec massif of 55.5

$\mathrm{m}^{3} /$ ha reflects the very good condition of the discussed forests, promoting biodiversity and the occurrence of saproxylic organisms. The coarse woody debris had the largest quantity (68\%) and thickness share (64\%) of the dead trees at the study plots. Analysis of the degree of dead tree decomposition revealed that the II degree was the most frequently represented phase of tree decomposition and that the diversity of decomposition progress was greater in coarse woody debris than in standing trees. The diversity of the coarse woody debris decomposition stages was also directly and proportionally related to the elevation of the plot above sea level. The evaluation of distribution structure of dead trees in stands demonstrated the clustered distribution of dead matter in the uppermost plot. On one hand, this spatial structure indicates the aggregate character of tree distribution in the stand, but on the other hand, it reflects the collective character of the self-thinning process.

Acknowledgements. The authors would like to thank the management staff of Bieszczady National Park for enabling the research and MSc Bolesław Kuźnik from the Bay Area Mycological Society, Berkeley, California, USA for his help in the identification of fungi.

\section{REFERENCES}

[1] Beran, M. (2004): Velký fotoatlas hub z Jižních Čech. - Papoušek T, Czeskie Budziejowice, Czech Republic.

[2] Bobiec, A. (ed.), Gutowski, J. M., Laudenslayer, W. F., Pawlaczyk, P., Zub, K. (2005): The Afterlife of a Tree. - Warsaw, WWF Poland, Brown, S.C. 
[3] Breitenbach, J., Kränzlin, F. (1986): Fungi of Switzerland. v.2: Non-Gilled Fungi. Verlag Mykologia, Luzern, Switzerland.

[4] Bruchwald, A. (1999): Dendrometria (Dendrometry). - Wydawnictwo SGGW, Warszawa (in Polish).

[5] Christensen, M., Hahn, K., Mountford, E. P., Ódor, P., Standovár, T., Rozenbergar, D., Diaci, J., Wijdeven, S., Meyer, P., Winter, S., Vrska, T. (2005): Dead wood in European beech (Fagus sylvatica) forest reserves. - Forest Ecology and Management 210: 26-282.

[6] Ciach, M. (2011): Martwe i zamierające drzewa w ekosystemie leśnym: ilość, jakość i zróżnicowanie (Dead and dying trees in forest ecosystem - quantity, quality, and diversity). - Studia i materiały w Rogowie 2 (27): 186-199 (in Polish, English abstract).

[7] Cooper, J., Kirk, P. (2012): Index fungorum. http://www.indexfungorum.org/Names/Names.asp.

[8] Czerepko, J. (ed.) (2008): Stan różnorodności biologicznej lasów w Polsce na podstawie powierzchni obserwacyjnych monitoringu (Status of forest biodiversity in Poland on the basis of the monitoring observation areas). - Synteza wyników uzyskanych w ramach realizacji projektu BioSoil Forest Biodiversity (Synthesis of the results obtained from the project BioSoil Forest Biodiversity). Instytut Badawczy Leśnictwa, Sękocin Stary. (In Polish, English, German summary).

[9] Czuraj, M., Radwański, B., Strzemeski, S. (1960): Tablice miąższości drzew stojących (Standing tree volume tables). - PWRiL, Warszawa (in Polish).

[10] Dudley, N., Vallauri, D. (2005): Restoration of deadwood as a critical microhabitat in forest landscapes. - In: Mansourian, S., Vallauri, D., Dudley, N. (eds.) Forest restoration in landscapes. Beyond planting trees. - Springer, New York.

[11] Ekbom, B., Schroeder, M. L., Larsson, S. (2006): Stand specific occurrence of coarse woody debris in a managed boreal forest in central Sweden. - Forest Ecology and Management 221: 2-12.

[12] Graham, B. F., Bormann, F. H. (1966): Natural root grafts. - Botanical Review 32 (3): 255-292.

[13] Gutowski, J. M. (2006): Saproksyliczne chrząszcze (Saproxylic beetles). - Kosmos. Problemy Nauk Biologicznych 55: 23-73 (in Polish).

[14] Gutowski, J. M. (ed.), Bobiec, A., Pawlaczyk, P., Zub, K. (2004): Drugie życie drzewa (The after life of a tree). - WWF Polska, Warszawa-Hajnówka.

[15] Heilmann-Clausen, J., Christensen, M. (2003): Fungal diversity on decaying beech logs implications for sustainable forestry. - Biodiversity Conservation 12 (5): 953-973.

[16] Holeksa, J., Maciejewski, B. (2009): Martwe drzewa i ich rola w ekosystemie leśnym (Dead trees and their role in forest ekosystem). - Roztoczańskie Spotkania 6: 68-82 (in Polish).

[17] Jankovský, L., Beránek, J., Vágner, A. (2004a): Dead Wood and mycoflora in Nature reserve Polom, protected Landscape Area Železné hory. - Journal of Forest Science 50 (3): 118-134.

[18] Jankovský, L., Lička, D., Ježek, K. (2004b): Inventory of dead wood in the KnéhynéCertův mlýn National Nature Reserve, the Moravian-Silesian Beskids. - Journal of Forest Science 50 (4): 171-180.

[19] Karaś, M. (1995): Naturalne biogrupy świerkowe a problem restytucji lasu w reglu górnym Gór Izerskich (Natural spruce biogroups and the issue of forest restitution in the upper layer of Izerskie Mountains). - Prace Instytutu Badawczego Leśnictwa ser. B 25/2: 235-250 (in Polish, English abstract).

[20] Kirby, K. J., Webster, S. D., Antczak, A. (1991): Effects of forest management on stand structure and the quantity of fallen dead wood: some British and Polish examples. - Forest Ecology and Management 43 (1-2): 167-174. 
[21] Kirby, K. J., Reid, C. M., Thomas, R.C., Goldsmith, F.B. (1998): Preliminary estimates of fallen dead wood and standing dead trees in managed and unmanaged forests in Britain. - Journal of Applied Ecology 35:148-155.

[22] Köster, K., Seedre, M., Tukia, H., Niklasson, M., Jögiste, K. (2004): Nature conservation and dead wood in forest ecosystems. - In: Kangur, A. (ed) Proceedings of the International conference" Natural Disturbances and Ecosystem-Based Forest Management", May 27-28, 2004, Tartu, Estonia.- Estonian Agricultural University, Estonia.

[23] Kraigher, H., Jurc, D., Kalan, P., Kutnar, L., Levanič, T., Rupel, M., Smolej, I. (2002): Beech coarse woody debris characteristics in two virgin forest reserves in southern Slovenia. - Zbornik gozdarstva in lesarstva 69: 91-134.

[24] Krankina, O. N., Harmon, M. E., Kukuev, Y. A., Treyfeld, R. F., Kashpor, N. N., Kresnov, V. G., Skudin, V. M., Protasov, N. A., Yatskov, M., Spycher, G., Povarov, E. D. (2002): Coarse woody debris in forest regions of Russia. - Canadian Journal of Forest Research 32 (5): 768-778.

[25] Kuś, J., Kuś, D. (2004): Entomofauna rozkładającego się drewna świerka, buka i brzozy na terenie Karkonoskiego Parku Narodowego (Entomofauna of spruce, beech and birch decaying wood in the Karkonoski National Park). - In: Štursa, J., Mazurski, K. R., Palucki, A., Potocka, J. (eds) Geoekologické problémy Krkonoš. - Mez. Věd. Konf., November 2003, Szklarska Poręba, Opera Corcontica 41: 269-280 (in Polish, English abstract).

[26] Loehle, C., Jones, R. H. (1990): Adaptive significance of root grafting in trees. Functional Ecology 4: 268-271.

[27] Maser, C., Anderson, R. G., Cromak Jr, K., Williams, J. T, Martin, R. E. (1979): Dead and down woody material. - In: Thomas, J. W. (ed) Wildlife habitats in managed forests: the blue mountains of Oregon and Washington. - USDA Forest Service, Agricultural Handbook No. 553, Portland-Washington D.C.

[28] Moeur, M. (1997): Spatial models of competition and gap dynamics in old-growth Tsuga heterophylla (Tsuga plicata) forest.- Forest Ecology and Management 94: 175-186.

[29] Müller, J., Bütler, R. (2010): A review of habitat thresholds for dead wood: a baseline for management recommendations in European forests. - European Journal of Forest Research129: 981-992.

[30] Müller-Using, S., Bartsch, N. (2009): Decay dynamic of coarse and fine woody debris of a beech (Fagus sylvatica L.) forest in Central Germany. - European Journal of Forest Research 128: 287-296.

[31] Nilsson, S. G., Niklasson, M., Hedin, J., Aronsson, G., Gutowski, J. M., Linder, P., Ljunberg, H., Mikusiński, G., Ranius, T. (2003): Densities of large living and dead trees in the old - growth temperate and boreal forests. - Forest Ecology and Management 161: 189-204.

[32] Nordén, B., Ryberg, M., Götmark, F., Olausson, B. (2004): Relative importance of coarse and fine woody debris for the diversity of wood-inhabiting fungi in temperate broadleaf forests. - Biological Conservation 117: 1-10.

[33] Oheimb, G., Westphal, C., Hárdtle, W. (2006): Diversity and spatial-temporal dynamics of dead wood in a temperate near natural beech forest (Fagus sylvatica). - European Journal of Forest Research 126: 359-370.

[34] Olsson, J. (2008): Colonization Patterns of Wood-inhabiting Fungi in Boreal Forests. Doctoral dissertation. Department of Ecology and Environmental Science, Umeå University, Umeå, Sweden.

[35] Ódor, P., Heilmann-Clausen, J., Christensen, M., Aude, E., Van Dort, K. W., Piltaver, A., Siller, I., Veerkamp, M. T., Walleyn, R., Standovár, T., Van Hees, A. F. M., Kosec, J., Matočec, N., Kraigher, H., Grebenc, T. (2006): Diversity of dead wood inhabiting fungi 
and bryophytes in semi-natural beech forests in Europe. - Biological Conservation 131 (1): 58-71.

[36] Pasierbek, T., Holeksa, J., Wilczek, Z., Żywiec, M. (2007): Why the amount of dead wood in Polish forest reserves is so small?. - Nature Conservation 64: 65-71.

[37] Piltaver, A., Matocec, N., Kosec, J., Jurc, D. (2002): Macrofungi on beech dead wood in the Slovenian forest reserves Rajhenavski Rog and Krokar. - Zbornik gozdarstva in lesarstva 69: 171-196.

[38] Piotrowski, W., Wołk, K. (1975): O biocenotycznej roli martwych drzew w ekosystemach leśnych (About biocenotic role of dead trees in forest ecosystems). Sylwan 8: 31-35 (in Polish, English summary).

[39] Pouska, V., Svoboda, M., Lepšová, A. (2010): The diversity of wood-decaying fungi in relation to changing site conditions in an old-growth mountain spruce forest, Central Europe. - European Journal of Forest Research 129 (2): 219-231.

[40] Przybylska, K., Ruciński, P., Karpierz, J. (1996): Zasady ochrony ekosystemów leśnych Bieszczadzkiego Parku Narodowego (Protection rules of forest ecosystems in Bieszczady National Park). - Roczniki Bieszczadzkie 5: 91-108 (in Polish, English summary).

[41] Rahman, M. M., Frank, G., Ruprecht, H., Vacik, H. (2008): Structure of coarse woody debris in Lang-Leitn Natural Forest Reserve, Austria. - Journal of Forest Science 54(4): 161-169.

[42] Rigg, G. B., Harrar, E. S. (1931): The root systems of trees growing in sphagnum. American Journal of Botany 18 (6): 391-397.

[43] Ripley, B. D. (1981): Spatial statistics. Wiley and Sons, New York.

[44] Solon, J., Wolski, J. (2002): Martwe drewno i jego funkcje ekologiczne w lasach zagospodarowanych i rezerwatach wybranych LKP. Ekologiczna rola martwego drewna w ekosystemach leśnych - dyskusja wybranych zagadnień w świetle literatury (In: Podstawy trwałego i zrównoważonego zagospodarowania lasów w Leśnych Kompleksach Promocyjnych) (Dead wood and its ecological functions in forests and selected LKP nature reserves. Ecological role of dead wood in forest ecosystems - the discussion of selected issues in the light of literature (In: Fundamentals of sustainable forest management in LKP) - Sprawozdanie z III etapu. Instytut Badawczy Leśnictwa, Sękocin Stary (in Polish).

[45] Starzyk, J., Grodzki, W., Kosibowicz, M., Michalcewicz, J., Rossa, R. (2008). - Stare i martwe drzewa jako miejsce występowania chrząszczy ksylobiontycznych i dendrofilnych (Old and dead trees as the site of occurence and development of xylobiotic and dendrophilous beetles). - Roczniki Bieszczadzkie 6: 325-348 (in Polish, English summary).

[46] Stevens, V. (1997): The ecological role of coarse woody debris: an overview of the ecological importance of CWD in B. C. forest. - Res. Br.,B., C. Min. For., Vicotria, B.C. Work.

[47] Szwagrzyk, J., Ptak, J. (1991): Analizy struktury przestrzennej populacji i zbiorowisk oparte na znajomości rozmieszczenia osobników (Analyses of spatial structure of population and communities based on mapped point patterns of individuals). Wiadomości Ekologiczne 37 (2): 107-123 (in Polish).

[48] Szymański, S. (2000): Ekologiczne podstawy hodowli lasu (Ecological basis of silviculture). - PWRiL, Warszawa (in Polish).

[49] Winnicki, T., Zemanek, B. (2003): Przyroda Bieszczadzkiego Parku Narodowego (Nature in the Bieszczady National Park). - Wydawnictwo „Impuls”, Kraków (in Polish).

[50] Winter, S., Flade, M., Schumacher, H., Kerstan, E., Möller, G. (2005): The importance of near natural stand structures for the biocoenosis of lowland beech forests. - Forest Snow and Landscape Research 79:127-144. 
[51] Wolski, J. (2002): Martwe drewno w lesie: Ocena zapasu i propozycje postępowania (Down deadwood in the forest: quantification and proposals for handling). - Prace Instytutu Badawczego Leśnictwa ser. A 953 (2): 23-45 (in Polish, English abstract). 